\title{
PENGARUH SUBTITUSI LIMBAH PERUT IKAN TONGKOL (EUTHYNNUS AFFINIS) PADA PAKAN TERHADAP PERTUMBUHAN DAN EFISIENSI PAKAN IKAN NILA (OREOCHROMIS NILOTICUS)
}

\author{
The Effect of Substitution of Tummy Fish (Euthynnus affinis) on Feed on the Growth and the Efficiency of Tilapia Feed
} (Oreochromis niloticus)

\author{
Agoeng Karyanto ${ }^{1}$, Hadijah $^{2}$, Erni Indrawati ${ }^{2}$ \\ ${ }^{1}$ SMK Negeri Kelautan Ansus Kabupaten Kepulauan Yapen, \\ ${ }^{2}$ Program Studi Budidaya Perairan Program Pascasarjana Universitas Bosowa
}

Email : agungkelautanansus@gmail.com

Diterima: 12 Desember 2019

Dipublikasikan: 05 Juli 2020

\begin{abstract}
ABSTRAK
Penelitian ini bertujuan untuk mengetahui pengaruh substitusi limbah perut ikan Tongkol (Euthynnus affinis) terhadap per-tumbuhan, efisiensi pakan dan konsentrasi yang optimal dalam meningkatkan pertumbuhan ikan Nila (Oreochromis niloticus) dan mengacu pada pemanfaatan bahan baku limbah usus ikan tongkol sebagai bahan alternatif pengganti bahan baku tepung ikan yang mahal. Penelitian ini merupakan jenis penelitian kuantitatif, menggunakan metode eksperimental yang terdiri atas 4 per-lakuan yaitu P0 (Protein 27\%), P1 (Protein 20\%), P2 (Protein 25\%), dan P3 (Protein 30\%). Data dianalisis dengan menggunakan analysis of variance (ANOVA). Parameter uji dalam penelitian ini meliputi Laju Pertumbuhan Spesifik, Pertumbuhan Mutlak, dan Efisiensi Pakan. Hasil penelitian menunjukkan rata-rata laju pertumbuhan spesifik benih ikan Nila (Oreochromis niloticus) berkisar antara 0.65-94\%, pertumbuhan mutlak berkisar antara 2-3 gr, efisiensi pakan berkisar antara 4-5\%, dan subtitusi tepung usus ikan tongkol (Euthynnus affinis) tidak berpengaruh nyata terhadap laju pertumbuhan spesifik (P $>0,05)$, sedangkan per-tumbuhan mutlak dan efisiensi pakan berpengaruh nyata terhadap subtitusi tepung usus ikan Tongkol (Euthynnus affinis) (p<0,05).
\end{abstract}

Kata Kunci: Ikan Nila, Subtitusi, Tepung Usus, Ikan Tongkol, Pertumbuhan, Efisiensi Pakan

\begin{abstract}
This study aims to determine the effect of substitution of Euthynnus affinis on growth, feed efficiency and optimal concentration in increasing the growth of tilapia (Oreochromis niloticus) and referring to the use of raw materials for tuna intestine waste as an alternative ingredient for the expensive fish flour starch. This study is quantitative research, using an experimental method consisting of 4 treatments, namely P0 (Protein 27\%), P1 (Protein 20\%), P2 (Protein 25\%), and P3 (Protein 30\%). Data were analyzed using analysis of variance (ANOVA). Test parameters in this study include Specific Growth Rate, Absolute Growth, and Feed Efficiency. The results showed that the average specific growth rate of tilapia seeds (Oreochromis niloticus) ranged from $0.65 \%$ to $0.94 \%$, absolute growth ranged from 2 gr to 3 gr, feed efficiency ranged from $4 \%$ to $5 \%$, and substitution of tuna fish intestine flour (Euthynnus affinis) did not significantly affect the specific growth rate (P>0.05), while absolute growth and feed efficiency significantly affected the substitution of flour of the tuna fish intestine (Euthynnus affinis) ( $p<0.05$ ).
\end{abstract}

Keywords: Tilapia, Substitution, Fish Colon Flour, Absolute Growth, Feed Efficiency

\section{PENDAHULUAN}

Ikan Nila (Oreochromis niloticus) merupakan komoditas air tawar yang cukup banyak dibudidayakan saat ini, baik kegiatan pembenihan maupun pembesaran. Ikan Nila (Oreochromis niloticus) memiliki keunggulan dibandingkan dengan beberapa ikan air tawar lainnya, seperti pertumbuhannya yang cepat, mudah untuk dikembangbiakkan, mudah dalam pemeliharaan dan adaptasi yang tinggi terhadap perubahan ling-kungan (Prihatini, 2013). Salah satu faktor penentu keberhasilan budidaya ikan nila (Oreochromis niloticus) adalah pakan. Afrianto dan Liviawaty (2005) menyatakan kebutuhan pakan mencapai 40-89\% dari keseluruhan komponen biaya produksi. Kebutuhan beberapa bahan pembuat pakan untuk budidaya ikan dalam negeri terus meningkat dan masih harus diimpor dengan harga yang tinggi. Salah satu cara untuk mengurangi kebutuhan bahan baku pakan impor adalah dengan memanfaatkan limbah perut ikan tongkol sebagai bahan baku pakan. Handari (2012), menyatakan bahwa prospek pembuatan pakan dari limbah perikanan cukup besar mengingat tingginya potensi limbah, yaitu 40-50\%. Efka $d k k$, (2005), menyatakan kandungan protein kasar limbah ikan berkisar $53,18 \pm 0,83 \%$. Oleh karena itu, perlu dilakukan usaha untuk pemanfaatan khususnya limbah usus ikan tongkol (Euthynnus affinis) sebagai produk yang lebih bernilai tambah dalam pemanfaatan bahan baku dalam pembuatan pakan ikan.

Tujuan penelitian ini yaitu untuk mengetahui pengaruh substitusi limbah perut ikan Tongkol (Euthynnus affinis) terhadap pertumbuhan dan efisiensi pakan pada ikan Nila (Oreochromis niloticus) serta mengetahui berapa konsentrasi limbah perut ikan Tongkol (Euthynnus affinis) yang optimal 
dalam meningkatkan pertumbuhan dan efisiensi pakan pada ikan Nila (Oreochromisniloticus).

\section{METODE PENELITIAN}

\section{Waktu dan Tempat}

Penelitian ini dilaksanakan di Balai Benih Ikan (BBI) Dinas Perikanan Kabupaten Kepulauan Yapen dan untuk analisa laboratorium menggunakan fasilitas Laboratorium $\mathrm{Nu}$ trisi dan Kimia Jurusan Budidaya Perikanan Politani Pangkep Sulawesi Selatan yang berlangsung dari bulan Oktober 2018 hingga Januari 2019.

\section{Metode Penelitian}

Penelitian ini merupakan jenis penelitian kuantitatif. Ikan uji yang digunakan pada penelitian adalah benih ikan Nila (Oreochromis niloticus) dengan ukuran berat rata- rata 1,5 $\pm 0,5 \mathrm{~g}$, panjang total $8,0 \pm 0,5 \mathrm{~cm}$ dan berumur 2 bulan. Pakan uji yang digunakan yaitu pakan komersil (Protein 27\%) sebagai kontrol dan pakan hasil subtitusi usus ikan tongkol (Euthynnus affinis) yang diformulasikan berdasarkan masingmasing jumlah protein yang akan di uji (Protein 20\%, Protein 25\% dan Protein 30\%).

Penelitian ini bersifat Eksperimental dengan metode Rancangan Acak Lengkap dengan 3 perlakuan dan 4 ulangan, yaitu :

- $\quad$ Perlakuan P0 = Protein 27\% (Pakan komersil)

- $\quad$ Perlakuan P1 = Protein $20 \%$

- $\quad$ Perlakuan P2 = Protein $25 \%$

- $\quad$ Perlakuan P3 = Protein $30 \%$

\section{Parameter Uji}

\section{Laju Pertumbuhan Spesifik}

Laju pertumbuhan spesifik merupakan parameter untuk mengamati tingkat pertumbuhan dan presentase pemambahan bobot harian (Effendie, 1997).

$$
\mathrm{SGR}=\frac{\ln W t-\ln W o}{t} \times 100 \%
$$

SGR = Laju pertumbuhan spesifik $(\mathrm{g} / \mathrm{hari})$

$\mathrm{Wt}=$ Bobot rata-rata ikan pada hari ke-t $(\mathrm{g})$

Wo = Bobot rata-rata ikan di awal penelitian $(\mathrm{g})$

$\mathrm{t} \quad=$ Waktu penelitian (hari)

\section{Pertumbuhan Mutlak}

Pertumbuhan mutlak merupakan parameter untuk mengukur laju pertumbuhan total ikan selama masa peme-liharaan (Effendie, 1997)

$$
W_{m}=W_{t}-W_{0}
$$

$\mathrm{W}_{m}=$ Pertumbuhan berat mutlak (Gram)

$\mathrm{W}_{t}=$ Berat biomassa pada akhir penelitian (Gram)

$\mathrm{W} o=$ Berat biomassa pada awal penelitian (Gram)

\section{Efisiensi Pakan}

Efisiensi pakan merupakan total pertambahan biomassa ikan dengan jumlah pakan yang dikonsumsi. Perhitungan efisensi pakan dilakukan menggunakan rumus Takeuchi (1988) sebagai berikut:

$$
\mathrm{FE}=\frac{\left(W_{t}+D\right)-W_{0}}{F} \times 100
$$

$$
\begin{array}{ll}
\mathrm{FE} & =\text { Efisiensi pakan }(\%) \\
\mathrm{F} & =\text { Bobot pakan yang diberikan }(\mathrm{g}) \\
\mathrm{Wt} & =\text { Bobot ikan pada akhir penelitian }(\mathrm{g}) \\
\mathrm{D} & =\text { bobot ikan yang mati }(\mathrm{g}) \\
\mathrm{Wo} & =\text { bobot ikan pada awal penelitian }(\mathrm{g})
\end{array}
$$

\section{Analisis Data}

Data Laju Pertumbuhan Spesifik (SGR), Pertumbuhan Mutlak dan Efisiensi Pakan dianalisa secara statistik dengan menggunakan Analysis of Variance (ANOVA). Hasil uji sidik ragam diketahui bahwa perlakuan menunjukkan pengaruh nyata $(\mathrm{P}<0,05)$, maka untuk membandingkan nilai antar perlakuan dilakukan uji lanjut denganBeda Nyata Terkecil (BNT).

\section{HASIL DAN PEMBAHASAN}

Hasil

\section{Laju Pertumbuhan Spesifik}

Berdasarkan pengamatan laju pertumbuhan spesifik, perlakuan P3 mempunyai nilai tertinggi pada hari ketujuh yaitu $1,58 \%$ perhari, diikuti P2 (Protein 25\%) yaitu 0,92\%, P1 (Protein 20\%) yaitu 0,47\% dan yang terendah pada P0 (Protein $27 \%$ ) yaitu $0,7 \%$. Pada pengamatan hari ke duapuluh delapan, laju pertumbuhan spesifik (SGR) harian mengalami penurunan pada perlakuan P3 (protein 30\%) dimana pada minggu ini perlakuan yang tertinggi ada pada perlakuan P0 (protein 27\%) sebesar $0.88 \%$ diikuti diikuti P1 (Protein 20\%) yaitu 0,82\%, P2 (Protein 25\%) yaitu $0,49 \%$ dan yang terendah pada P3 (Protein $30 \%$ ) yaitu $0,37 \%$.

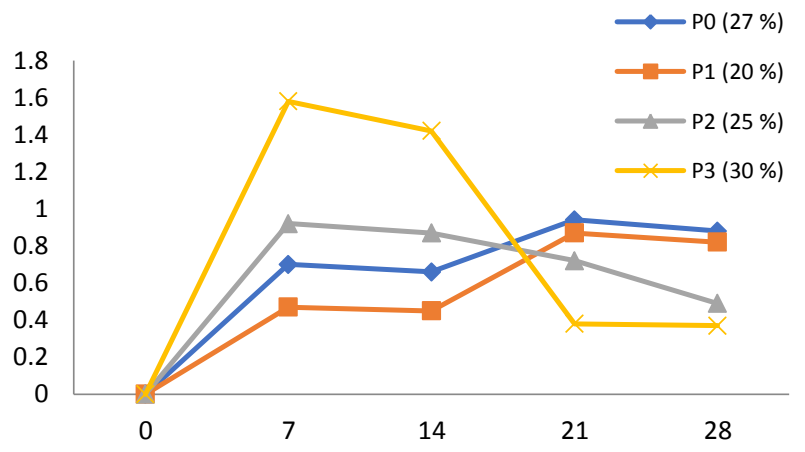

Gambar 1. Diagram Laju Pertumbuhan Spesifik

Hasil analisa ragam ANOVA bahwa perlakuan pemberian tepung limbah perut ikan Tongkol tidak berpengaruh terhadap laju pertumbuhan spesifik (SGR) $(\mathrm{P}>0,05)$.

\section{Pertumbuhan Mutlak}

Berdasarkan pengamatan pertumbuhan mutlak, perlakuan tertinggi terdapat pada perlakuan P3 (protein 30\%) yaitu sebesar $3 \mathrm{gr} \pm 0.00$, diikuti perlakuan P0 (protein 27\%) yaitu 2,5 gr \pm 0.00 , perlakuan P2 (Protein 25\%) yaitu 2,3 gr $\pm 0,29$ dan yang terendah pada perlakuan P1 (protein 20\%) sebesar $2 \mathrm{gr} \pm$ 0.00 


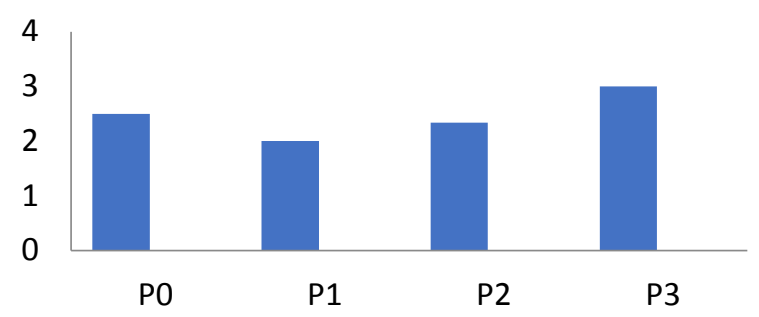

Gambar 2. Diagram Laju Pertumbuhan mutlak

Hasil analisa ragam ANOVA bahwa perlakuan pemberian tepung limbah perut ikan Tongkol berpengaruh terhadap laju pertumbuhan mutlak $(\mathrm{P}<0,05)$.

\section{Efisiensi Pakan}

Berdasarkan pengamatan nilai efisiensi pakan, perlakuan tertinggi terdapat pada perlakuan P3 (protein 30\%) yaitu sebesar $5 \% \pm 0.00$, sedangkan yang terendah pada perlakuan $\mathrm{P} 0$ (Kontrol) sebesar $4 \% \pm 0.00$.

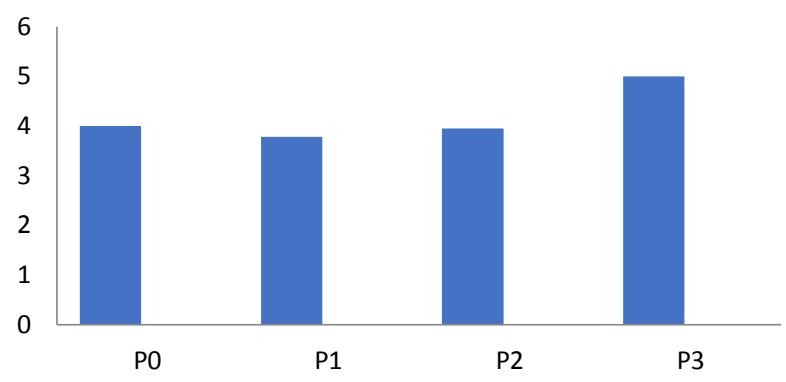

Gambar 3. Diagram efisiensi pakan

Hasil analisa ragam ANOVA bahwa perlakuan pemberian tepung limbah perut ikan Tongkol berpengaruh terhadap efisiensi pakan mutlak $(\mathrm{P}<0,05)$.

\section{Pembahasan}

\section{Laju Pertumbuhan Spesifik}

Nilai laju pertumbuhan spesifik menunjukkan bahwa perlakuan pemberian tepung limbah perut ikan Tongkol (Euthynnus affinis) yang diukur pertujuh hari dalam masa waktu penelitian 28 hari mendapatkan nilai tertingginya pada perlakuan P3 (protein 30\%) sebesar $1.58 \%$ dan terendah pada perlakuan P0 (protein 27\%) sebesar $0.7 \%$. Tingginya tingkat laju pertumbuhan spesifik pada hari ke tujuh berhubungan dengan terpenuhnya asupan kebutuhan nutrisi serta kemampuan ikan memanfaatkan pakan menjadi energi yang digunakan untuk pertumbuhan. Menurut BBAT (2005) ikan Nila (Oreochromis niloticus) tumbuh maksimal pada pemberian pakan dengan kadar protein 25-30\%.

Rendahnya tingkat pertumbuhan spesifik terhadap protein pakan pada hari ke 28 di sebabkan tingginya kandungan serat kasar yang terkandung didalam pakan. Dimana kandungan serat kasar yang tinggi didalam pakan akan mempengaruhi daya cerna protein dan penyerapan zat-zat makanan didalam alat pencernaan ikan dikarenakan serat kasar yang terdapat didalam pakan tidak bisa dirombak. Berdasarkan hasil uji analisis proksimat terhadap pakan yang digunakan dalam penelitian didapatkannya hasil pakan P0 (Karbohidrat 60.25\%), pakan P1 (Karbohidrat 55.67\%), pakan P2 (Karbohidrat $52.69 \%$ ) dan pakan P3 (Karbohidrat 45.61\%). Hasil dari analisis proksimat ini menunjukkan bahwa kebutuhan karbohidrat ikan Nila (Oreochromis niloticus) sudah melewati batas kebutuhan. Tawab (2012) mengatakan bahwa kadar karbohidrat optimal untuk ikan omnivora berkisar antara 30\%-40\% dan serat kasar merupakan bagian dari karbohidrat yang tidak dapat dicerna. Haetami dan sastrawibawa (2005) mengatakan bahwa ikan Nila (Oreochromis niloticus) yang mengkonsumsi pakan dengan kandungan serat kasar tinggi akan memiliki daya cerna yang rendah.

\section{Pertumbuhan Mutlak}

Laju pertumbuhan mutlak menunjukkan bahwa perlakuan pemberian tepung limbah perut ikan Tongkol (Euthynnus affinis) mendapatkan nilai pengukuran pertumbuhan mutlak masih tergolong rendah dikarenakan efisiensi pakan yang rendah. Dalam masa penelitian selama 28 hari, pertumbuhan mutlak hanya bisa mencapai tingkat pertumbuhan antara $2 \mathrm{gr}-3 \mathrm{gr}$ dimana yang tertinggi ada pada perlakuan P3 (protein $30 \%$ ) dan terendah P1 (protein 20\%). Hal ini masih sama dengan yang terjadi pada tingkat kelangsungan hidup (SGR) dimana kandungan serat kasar pada pakan semakin tinggi sehingga kurangnya daya cerna ikan terhadap pakan. Walaupun nilai kandungan protein pakan yang diformulasikan masih berada pada kisaran kebutuhan untuk ikan Nila (Oreochromis niloticus) tetapi penyerapan terhadap protein pakan masih kurang. Inilah yang menyebabkan pertumbuhan mutlak berada pada kisaran yang rendah. Hal ini sesuai dengan pernyataan Fujaya (2004), yaitu cepat tidaknya pertumbuhan ikan ditentukan oleh banyaknya protein yang dapat diserap dan dimanfaatkan oleh tubuh sebagai zat pembangun. Serat kasar yang tinggi menyebabkan porsi ekskreta lebih besar, sehingga menyebabkan berkurangnya masukan protein yang dapat dicerna (Handajani, 2017)

\section{Efisiensi Pakan}

Berdasarkan hasil penelitian menunjukan bahwa subtitusi perut ikan Tongkol (Euthynnus affinis) sebagai bahan baku pakan tidak berpengaruh pada tingkat efisiensi pakan, dimana nilai efisiensi pakan pada setiap perlakuan sangat rendah yakni berkisar antara 4-5\%. Hasil ini masih belum memenuhi standar efisiensi pakan untuk pertumbuhan ikan nila (Oreohromis niloticus) yang dimana jika hasil ini dibandingan dengan ratarata efisiensi pakan untuk ikan perairan tawar yaitu ikan nila mencapai $50.23 \%$, patin $73.1 \%$, ikan mas $53.45 \%$ dan gurame mencapai 45.75\% (Sugianto, 2007). Subekti dkk, (2019), efisiensi pakan yang tinggi menunjukkan penggunaan pakan yang efisien, sehingga hanya sedikit protein yang dirombak untuk memenuhi kebutuhan energi dan selebihnya digunakan untuk pertumbuhan. Semakin tinggi nilai efisiensi protein suatu pakan berarti semakin efisien penggunaan protein pakan tersebut dalam menunjang pertumbuhan.

Rendahnya tingkat efisiensi pakan dikarenakan proses sintesa protein pakan oleh enzim protease tidak berjalan optimal karena pakan mengandung serat kasar yang tinggi. 
Hasil analisis proksimat pakan menunjukkan tingginya kandungan serat kasar yang terdapat didalam karbohidrat dimana P0 (Karbohidrat 60.25\%), pakan P1 (Karbohidrat 55.67\%), pakan P2 (Karbohidrat 52.69\%) dan pakan P3 (Karbohidrat 45.61\%) (lampiran 3). Penelitian Fujaya (2004), mengemukaan bahwa nilai kecernaan yang tinggi terkait dengan serat kasar yang terkandung di dalam pakan, semakin rendah kadar serat kasar maka ikan akan lebih mudah mencerna dan menyerap nutrien termasuk protein.

Faktor lain dari rendahnya efisiensi pakan yaitu kandungan protein pakan yang dipengaruhi oleh keseimbangan antara protein dan energi, komposisi asam amino, dan kecernaan protein. Restiningtyas $d k k,(2015)$, menyatakan bahwa tingkat kecernaan terhadap suatu jenis pakan bergantung kepada kualitas pakan, komposisi bahan pakan, kandungan gizi pakan, jenis serta aktivitas enzim-enzim pencernaan pada sistem pecernaan ikan, ukuran dan umur ikan serta sifat fisik dan kimia perairan.

\section{KESIMPULAN}

Subtitusi tepung usus ikan tongkol (Euthynnus affinis) tidak berpengaruh nyata terhadap laju pertumbuhan spesifik, sedangkan pertumbuhan mutlak dan efisiensi pakan berpengaruh nyata terhadap subtitusi tepung usus ikan tongkol. Konsentrasi substitusi limbah perut ikan Tongkol (Euthynnus affinis) yang optimal terdapat pada pertumbuhan mutlak dan efisiensi pakan.

\section{DAFTAR PUSTAKA}

Affrianto, E. dan E. Liviawaty. (2005). Pakan Ikan. Kanisius. Yogyakarta

BBAT Sukabumi. 2005. Kandungan Nutrisi Ikan Nila. SNI023151-2005. Sukabumi Jawa Barat. Jawa Barat. 77 hlm

Effendie, M.I. (1979). Metode Biologi Perikanan. YayasanDewi Sri Bogor Indonesia, $122 \mathrm{pp}$.

Nelson, J. S. (2006). Fishes of the World. Fourth Edition. John Wiley and Sons. Inc., New York, USA. 601 p.

Prihatini, E. S. (2013). Studi Tentang Perbedaan Laju Pertumbuhan Ikan Nila (Oreochomis niloticus) yang menggunakan dan yang tidak menggunakan Pupuk Organik Cair. Skripsi. Program Studi Manajemen Sumber Daya Perairan, Universitas Islam Lamongan.

Restiningtyas, R., Subandiyono and Pinandoyo (2015) 'Pemanfaatan Tepung Daun Lamtoro (Laucaena Gluca) Yang Telah Difermentasikan Dalam Pakan Buatan Terhadap Pertumbuhan Benih Ikan Nila Merah (Oreochromis Niloticus)', Journal of Aquaculture Management and Technology.

Sugianto, D. (2007). Pengaruh tingkat pemberian maggot terhadap pertumbuhan dan efisiensi pemberian pakan benih ikan gurame (Osphronemus gouramy). Skripsi. Intitut Pertanian Bogor. Skripsi. Institut Pertanian Bogor. Fakultas Perikanan dan Ilmu Kelautan. Departemen Budidaya Perairan. Bogor.

Subekti, S., Arief, M. and Prakosa Yudha, G. C. (2019) 'Substitusi Silase Secara Kimiawi Limbah Padat Surimi
Ikan Swanggi (Priacanthus macracanthus) Pada Tepung Ikan Terhadap Retensi Protein Dan Retensi Lemak Ikan Nila (Oreochromis niloticus) [Silage substitution Chemically Solid Waste Surimi Fish Swanggi (Priacanthus macracanthus) on to Retention Protein Fish Meal and Retention Fat Tilapia (Oreochromis niloticus)]', Jurnal Ilmiah Perikanan dan Kelautan. doi: 10.20473/jipk.v8i2.11180.

SNI. 7550. (2009). Standart Nasional Indonesia Produksi Ikan Nila (Oreochromis nilotikus) Kelas Pembesaran di Kolam air Tenang

Tawwab, M, A. 2012. Effect of Dietary Protein Levels and Rearing Density on Growth Performance and Stress Response of Nile Tilapia, Oreochromis niloticus (L). International Aquatic Research. Vol.(4): 1-13

Takeuchi, T. (2002). Laboratory Work - Chemical evaluation of Dietary nutrients. P. 179-233. In: Watanabe, T. (Ed). Fish Nutrition and Mariculture JICA Textbook. The General Aquaculture Course. Kanagawa international Fisheries Training Centre. Japan international Cooperation Agency (JICA). 233 PP. 